\title{
Provisions of Disabled Facilities at The Malaysian Public Transport Stations
}

\author{
Haryati Mohd Isa ${ }^{1, a}$, Halmi Zanol ${ }^{2}$, Kartina Alauddin ${ }^{1}$ and Mohd Hafizuddin $\mathrm{Nawi}^{3}$ \\ ${ }^{1}$ Dr, Quantity Surveying Department, Faculty of Architecture, Planning and Surveying, UiTM Perak Branch, Malaysia \\ ${ }^{2}$ Assoc. Prof, Dr, Town and Regional Planning, Faculty of Architecture, Planning and Surveying, UiTM Perak Branch, Malaysia \\ ${ }^{3}$ Quantity Surveying Department, Faculty of Architecture, Planning and Surveying, UiTM Perak Branch, Malaysia
}

\begin{abstract}
Public transport stations need to provide access and facilities for people with disabilities (PWD) in fulfilling the requirements of the Malaysian Standard Code of Practice on Access of Disabled Persons (MS). However, most public transport stations in Malaysia are reported as still lacking in terms of providing good designs and facilities for the PWDs. This inaccessible environment affects the PWDs to negatively participate in the social and economic mainstream. The research aims at identifying the compliance of disabled facilities provided at the electronic train service (ETS) railway station in Perak. Two research objectives were established (1) to identify the range of disabled facilities provided at the ETS railway station in Perak and (2) to determine the compliance of the disabled facilities as outlined in the MS. Eight ETS railway stations in Perak were chosen for the case study. Purely qualitative methods were adopted. An observation checklist was developed by conducting document analysis on three main documents. The findings suggest that there are 14 disabled facilities to be provided at the ETS railway stations. Majority of these facilities are available and comply with the MS. Conversely, some improvement can be made to further promote sustainability atmosphere of the ETS railway stations.
\end{abstract}

\section{Introduction}

Malaysia is moving towards Vision 2020 to be a fully developed country. Under this vision, nine challenges had been outlined. Amongst them is to establish a fully caring society and culture, in which the welfare of the people will revolve around a strong and resilient family system. This also includes people with disabilities (PWDs). The Persons with Disabilities Act 2008 (Act 685) (PWDA) stressed that PWDs shall have the same rights to access and use public facilities, amenities, services and buildings. The needs of the PWDs in the development cannot be ignored [1] and [2]. As in Malaysia, it is a mandatory for all public buildings to provide access and facilities for PWDs since the requirements to fulfill the Malaysian Standard (MS) are stated in the Uniform Building (Amendment) By-Laws (UBBL) 1991. The implementation of these codes of practice has always been highlighted [3] and [4]. Conversely, [5] reported that Malaysia is still lacking in considering equal accessibility and facilities for this group.

With regard to this problem, a research was mooted to identify the compliance of disabled facilities provided at the electric train service (ETS) railway station in Perak. In line with this aim, two objectives were established to operationalize the research: (1) to identify the range of disabled facilities provided at the ETS railway station in Perak (2) to determine the compliance of the disabled facilities provided as outlined in the MS.

\footnotetext{
a harya966@perak.uitm.edu.my
}

\section{Literature review}

\subsection{Persons with disabilities (PWD) generally}

The Persons with Disabilities Act 2008 (Act 685) (PWDA) defines PWDs as persons with physical, mental and intellectual disabilities that hindered them from fully participating in a normal way in the community way of life. This includes people with impairment, senior citizens, or even a pregnant woman. According to [6], impairment can be divided into three categories namely hearing impairment, visual impairment and physical/mobility impairment. People become disabled when society fails to accommodate them in social and infrastructural development, either purposely or inadvertently [7]. Consequently, this will affect not only the person with impairment, but also to the affected family [8].

The United Nations estimates that there are 650 million disabled people in the world which corresponds to $10 \%$ of global population [9]. In 2010, Statistics Department reported that there are approximately 5.1\% PWDs in Malaysia and this figure had increased annually. Thus, this resulted a demand for the provisions of access and facilities in and outside a building, especially in public services. Indeed, this should be a crucial element to be considered in reducing the mobility 
constraints of PWDs. Furthermore, [9] added that the simplest way of increasing the use of public transportation facilities is by establishing a safe, convenient and comfortable environment for the full participation of these citizens. However, several researchers revealed that the present provisions are inadequate and not disabled friendly $[10,4,5]$. This suggests for serious action to be taken by the government as the public facility provider.

\subsection{Relevant legislation, statutory and guidelines}

Various acts and legislation have been created for PWDs rights in developed as well as developing countries. The establishment of such standards rules and legislation signify a strong ethical value and positive support from the government to ensure equal rights for all citizens. It also serves as guidelines for the professionals to plan and design their tasks. In Malaysia, the government had established The Persons with Disabilities Act 2008 (Act 685), Uniform Building (Amendment) By-Laws (UBBL) 1991 and Malaysian Standards i.e ; MS 1183:1990 Code of Practice for Means of Escape for Disabled Persons, MS 1184:2002 Code of Practice on Access for Disabled Persons to Public Buildings (1st revision) and MS 1331:2003 Code of Practice on Access for Disabled Persons Outside Buildings (1st revision).

\subsection{Accessibility for PWDs}

Although Malaysia offers technologically advanced services and facilities, not all of the societies are able to conduct their activities. Amongst the reason is lack of physical access for the PWDs. The facilities provided do not cover all categories of PWDs [11]. He also added that despite of the legislation, statutory and guidelines available, there is still lack of compliance made by the building owners. Furthermore, [4] argued that the access and facilities provided at the public transportation terminal is designed inefficiently and leads to a limited space for the PWDs to move about. Realising this problem, access audit should be conducted to ensure the compliance of those requirements as set in the MS.

\section{Research methodology}

Eight ETS railway stations in Perak were chosen for observation. An observation checklist was developed prior to conducting document analysis on three main documents i.e The Persons with Disabilities Act 2008 (Act 685), UBBL 1991 and MS.

The purpose of conducting the observation was to observe the compliance of the existing disabled facilities provided in the case studies. Table 1 shows a sample of the checklist used during the observation. After the observation was conducted, the entire checklist was by using descriptive analysis to determine types of facilities provided and the compliance of each of the facilities provided at all stations to the standard provided.
Table 1. Observation checklist for disabled facilities at ETS railway stations in Perak

\begin{tabular}{|c|c|}
\hline Station: & Time: \\
\hline Standards & Availability \\
\hline PWD Parking & \\
\hline a) Located at the main entrance & \\
\hline b) Located at the flat surface & \\
\hline c) With adequate width $(2400 \mathrm{~mm})$ & \\
\hline $\begin{array}{l}\text { d) There is a signage indicating the } \\
\text { parking }\end{array}$ & \\
\hline $\begin{array}{lll}\text { e) Marking indicating } & \text { disabled } \\
\text { parking }\end{array}$ & \\
\hline $\begin{array}{l}\text { f) Enough space for wheelchair user } \\
\text { to manoeuvre (extra space min } \\
900 \mathrm{~mm} \text { ) }\end{array}$ & \\
\hline Walkway & \\
\hline a) Surface with non-slip & \\
\hline $\begin{array}{l}\text { b) Clear width ( } \min 1200 \mathrm{~mm} \text { - enable } \\
\text { wheelchair) }\end{array}$ & \\
\hline c) Properly connected & \\
\hline Ramp and kerb & \\
\hline $\begin{array}{l}\text { a) Ramp consists of landing (min } \\
\text { length } 1200 \mathrm{~mm} \text { ) at interval of not } \\
\text { more than } 600 \mathrm{~mm} \text { length of ramp) }\end{array}$ & \\
\hline b) Surface with non-slip & \\
\hline $\begin{array}{l}\text { c) Enable wheelchair user(1200mm } \\
\text { min width) }\end{array}$ & \\
\hline $\begin{array}{l}\text { d) Proper gradient (Max 1:12-min } \\
1: 20)\end{array}$ & \\
\hline $\begin{array}{l}\text { e) Provided with handrails at both } \\
\text { sides }\end{array}$ & \\
\hline $\begin{array}{l}\text { f) Kerb is provided at both sides (min } \\
100 \mathrm{~mm} \text { length) }\end{array}$ & \\
\hline Doorway/Main entrance & \\
\hline $\begin{array}{l}\text { a) Doorway width is adequate for } \\
\text { wheelchair user (min 900mm } \\
\text { width) }\end{array}$ & \\
\hline $\begin{array}{l}\text { b) Threshold is leveled with step ramp } \\
\text { (if any) }\end{array}$ & \\
\hline Guiding block/Tactile & \\
\hline a) Installed at proper location & \\
\hline $\begin{array}{l}\text { b) Each block is installed adjacent to } \\
\text { one another }\end{array}$ & \\
\hline c) Contrast in colour & \\
\hline d) Detectable underfoot & \\
\hline Handrail & \\
\hline $\begin{array}{l}\text { a) Fixed with proper height at ramp } \\
\text { (min } 840-900 \mathrm{~mm} \text { in height) }\end{array}$ & \\
\hline $\begin{array}{l}\text { b) At ramp/stairway }- \text { extended } \\
\text { 300mm in length at both sides }\end{array}$ & \\
\hline c) Contrast in colour & \\
\hline d) Surface with non-slip grip & \\
\hline $\begin{array}{l}\text { Special lane for wheelchair user to } \\
\text { Platform } 2\end{array}$ & \\
\hline a) Surface with non-slip & \\
\hline b) Clear width (min $1200 \mathrm{~mm})$ & \\
\hline
\end{tabular}




\begin{tabular}{|c|c|}
\hline \multicolumn{2}{|l|}{ Staircase } \\
\hline a) Tread with non-slip surface & \\
\hline b) Tread width (260-300mm) & \\
\hline c) Riser height (max 180mm) & \\
\hline d) Handrails provided at both sides & \\
\hline $\begin{array}{l}\text { e) Landing and floor contrast in } \\
\text { colour/brightness/texture to the stairs }\end{array}$ & \\
\hline \multicolumn{2}{|l|}{ Prayer room } \\
\hline a) Ablution area accessible to wheelchair user & \\
\hline b) Door width accessible to wheelchair user & \\
\hline c) Step ramp at door & \\
\hline d) Floor with non-slip surface & \\
\hline \multicolumn{2}{|l|}{ Disabled toilet } \\
\hline $\begin{array}{l}\text { a) Have adequate space for wheelchair user } \\
\text { (min } 2000 \times 3400 \mathrm{~mm} \text { and for ambulant } \\
\text { disabled } \min 1200 \times 2400 \mathrm{~mm} \text { ) }\end{array}$ & \\
\hline b) Handrail is provided & \\
\hline $\begin{array}{l}\text { Water closet }- \text { pedestal }(450 \mathrm{~mm}-460 \mathrm{~mm} \\
\text { height) }\end{array}$ & \\
\hline d) Wash hand basin (800-830mm height) & \\
\hline e) Accessible tap with flexible hose & \\
\hline $\begin{array}{l}\text { f) Adequate door width (1200mm for } \\
\text { wheelchair user or } 900 \mathrm{~mm} \text { for ambulant } \\
\text { disabled) }\end{array}$ & \\
\hline \multicolumn{2}{|l|}{ Signage } \\
\hline a) Clearly shows the direction/information & \\
\hline b) Signage & \\
\hline c) Signage is equipped with braille instruction & \\
\hline $\begin{array}{l}\text { d) Signage is installed at proper locations; } \\
\text { - Parking area } \\
\text { - Walkway } \\
\text { - Main entrance/doorway } \\
\text { - Toilet/washroom } \\
\text { - Platform } \\
\text { - Ticket counter }\end{array}$ & \\
\hline \multicolumn{2}{|l|}{ Elevator } \\
\hline $\begin{array}{l}\text { a) Accessible to wheelchair user (door width } \\
800-1000 \mathrm{~mm} \text { ) }\end{array}$ & \\
\hline b) Guiding block is provided at the elevator & \\
\hline $\begin{array}{l}\text { c) Handrail } 600 \mathrm{~mm} \text { long and } 1000 \mathrm{~mm} \text { above } \\
\text { floor }\end{array}$ & \\
\hline $\begin{array}{l}\text { d) All control buttons not higher than } 1400 \mathrm{~mm} \\
\text { above finished floor }\end{array}$ & \\
\hline $\begin{array}{l}\text { e) Enough space for wheelchair user to } \\
\text { maneuver in the elevator }(1800 \times 1800 \mathrm{~mm})\end{array}$ & \\
\hline Escalator & \\
\hline Guiding block is provided at the elevator & \\
\hline
\end{tabular}

\section{Findings}

\subsection{Types of disabled facilities to be provided at ETS railway stations}

Figure 1 shows the range of types of facilities to be provided at the public railway stations. There are 14 types of disabled facilities to be provided in ETS railway stations namely disabled parking, walkway, ramp and kerb, doorway at main entrance, guiding block, handrail, staircase, signage, disabled toilet, ticket counter, elevator, escalator, prayer room and special lane for wheelchair users to Platform 2.

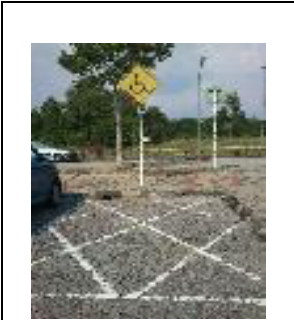

Disabled parking

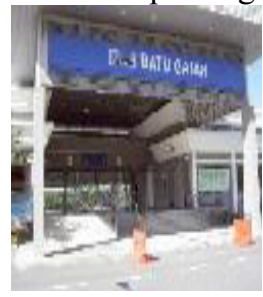

Doorway at main entrance

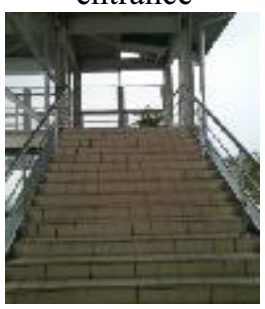

Staircase

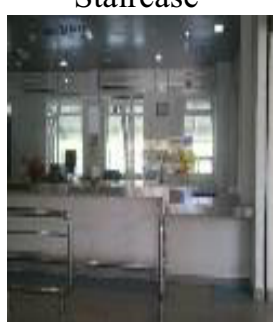

Ticket counter

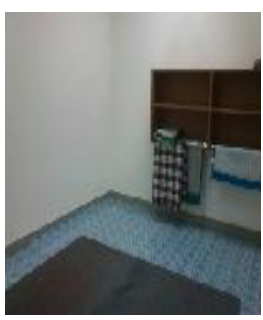

Prayer room

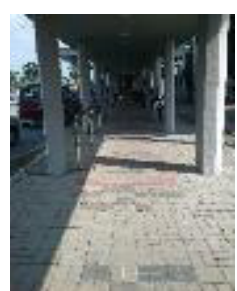

Walkway

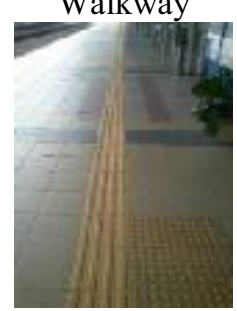

Guiding block

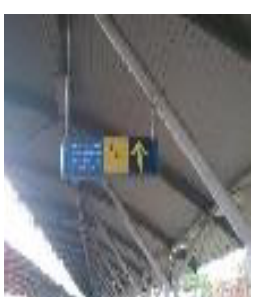

Signage

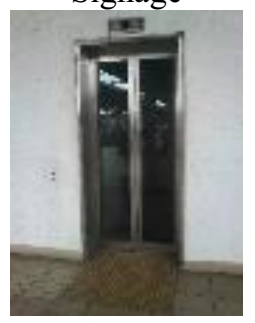

Elevator

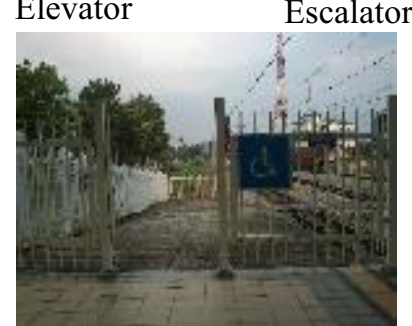

Special lane for wheelchair user to Platform 2
Figure 1. Types of disabled facilities to be provided at ETS railway station

Table 2 presents the availability of disabled facilities at ETS railway stations in Perak. Generally, all of the facilities are available at all stations. RS1 and RS3 are two most equipped stations with disabled facilities provided. Majority of the PWD facilities are provided at all stations namely disabled parking, walkway, ramp and kerb, doorway at man entrance, guiding block, handrail, staircase, signage, disabled toilet, ticket counter and special lane for wheelchair user to Platform 2. 
Table 2. Availability of the disabled facilities in ETS railway stations in Perak

\begin{tabular}{|c|c|c|c|c|c|c|c|c|c|c|c|}
\hline \multirow{2}{*}{\multicolumn{2}{|c|}{ Facilities }} & \multicolumn{8}{|c|}{ Availability } & \multirow[b]{2}{*}{$\%$} & \multirow{2}{*}{ 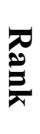 } \\
\hline & & $\mathbf{R S}$ & $\mathbf{R S}$ & $\mathbf{R S}$ & $\mathbf{R S}$ & $\mathbf{R S}$ & $\mathbf{R S}$ & $\mathbf{R S}$ & $\mathbf{R S}$ & & \\
\hline 1. & Disabled parking & $\sqrt{ }$ & $\sqrt{ }$ & $\sqrt{ }$ & $\sqrt{ }$ & $\sqrt{ }$ & $\sqrt{ }$ & $\sqrt{ }$ & $\sqrt{ }$ & 100 & 1 \\
\hline 2. & Walkway & $\sqrt{ }$ & $\sqrt{ }$ & $\sqrt{ }$ & $\sqrt{ }$ & $\sqrt{ }$ & $\sqrt{ }$ & $\sqrt{ }$ & $\sqrt{ }$ & 100 & 1 \\
\hline 3. & Ramp and kerb & $\sqrt{ }$ & $\sqrt{ }$ & $\sqrt{ }$ & $\sqrt{ }$ & $\sqrt{ }$ & $\sqrt{ }$ & $\sqrt{ }$ & $\sqrt{ }$ & 100 & 1 \\
\hline 4. & Doorway at main entrance & $\sqrt{ }$ & $\sqrt{ }$ & $\sqrt{ }$ & $\sqrt{ }$ & $\sqrt{ }$ & $\sqrt{ }$ & $\sqrt{ }$ & $\sqrt{ }$ & 100 & 1 \\
\hline 5. & Guiding block & $\sqrt{ }$ & $\sqrt{ }$ & $\sqrt{ }$ & $\sqrt{ }$ & $\sqrt{ }$ & $\sqrt{ }$ & $\sqrt{ }$ & $\sqrt{ }$ & 100 & 1 \\
\hline 6. & Handrail & $\sqrt{ }$ & $\sqrt{ }$ & $\sqrt{ }$ & $\sqrt{ }$ & $\sqrt{ }$ & $\sqrt{ }$ & $\sqrt{ }$ & $\sqrt{ }$ & 100 & 1 \\
\hline 7. & Staircase & $\sqrt{ }$ & $\sqrt{ }$ & $\sqrt{ }$ & $\sqrt{ }$ & $\sqrt{ }$ & $\sqrt{ }$ & $\sqrt{ }$ & $\sqrt{ }$ & 100 & 1 \\
\hline 8. & Signage & $\sqrt{ }$ & $\sqrt{ }$ & $\sqrt{ }$ & $\sqrt{ }$ & $\sqrt{ }$ & $\sqrt{ }$ & $\sqrt{ }$ & $\sqrt{ }$ & 100 & 1 \\
\hline 9. & Disabled toilet & $\sqrt{ }$ & $\sqrt{ }$ & $\sqrt{ }$ & $\sqrt{ }$ & $\sqrt{ }$ & $\sqrt{ }$ & $\sqrt{ }$ & $\sqrt{ }$ & 100 & 1 \\
\hline 10. & Ticket counter & $\sqrt{ }$ & $\sqrt{ }$ & $\sqrt{ }$ & $\sqrt{ }$ & $\sqrt{ }$ & $\sqrt{ }$ & $\sqrt{ }$ & $\sqrt{ }$ & 100 & 1 \\
\hline 11. & Elevator & $\sqrt{ }$ & $\mathrm{x}$ & $\sqrt{ }$ & $\mathrm{x}$ & $\mathrm{x}$ & $\mathrm{x}$ & $\mathrm{x}$ & $\mathrm{x}$ & 25 & 3 \\
\hline 12. & Escalator & $\sqrt{ }$ & $\mathrm{x}$ & $\mathrm{X}$ & $\mathrm{x}$ & $\mathrm{x}$ & $\mathrm{x}$ & $\mathrm{x}$ & $\mathrm{x}$ & 13 & 4 \\
\hline 13. & Prayer room & $\mathrm{x}$ & $\sqrt{ }$ & $\sqrt{ }$ & $\sqrt{ }$ & $\sqrt{ }$ & $\sqrt{ }$ & $\sqrt{ }$ & $\sqrt{ }$ & 88 & 2 \\
\hline 14. & $\begin{array}{l}\text { Special lane for wheelchair user to } \\
\text { Platform } 2\end{array}$ & $\sqrt{ }$ & $\sqrt{ }$ & $\sqrt{ }$ & $\sqrt{ }$ & $\sqrt{ }$ & $\sqrt{ }$ & $\sqrt{ }$ & $\sqrt{ }$ & 100 & 1 \\
\hline \multicolumn{2}{|l|}{$\%$} & 93 & 86 & 93 & 86 & 86 & 86 & 86 & 86 & & \\
\hline \multicolumn{2}{|c|}{ Rank } & 1 & 2 & 1 & 2 & 2 & 2 & 2 & 2 & & \\
\hline
\end{tabular}

Note: $\sqrt{ }$ Available $\mathrm{x}$ Not available

Three most uncommon facilities provided at all ETS stations in Perak are prayer room, elevator and escalator. Only RS1 has an escalator because it is the biggest ETS station and caters for the largest amount of passengers. However, there is no prayer room provided in this station since it is constructed during the colonial era. Meanwhile, it is also found that elevator is only provided at RS1 and RS3.

\subsection{Analysis of the compliance of the disabled facilities provided at the ETS railway stations with the MS}

\subsubsection{Analysis of walkway}

There are three standards of walkway to be complied such as surface with non-slip, clear width of minimum $1200 \mathrm{~mm}$ and properly connected.

Table 3. Analysis of walkway towards MS

\begin{tabular}{|l|c|c|c|c|c|c|c|c|}
\hline \multirow{2}{*}{ Standards } & \multicolumn{7}{|c|}{ Compliance } \\
\cline { 2 - 8 } & $\mathrm{R}$ & $\mathrm{R}$ & $\mathrm{R}$ & $\mathrm{R}$ & $\mathrm{R}$ & $\mathrm{R}$ & $\mathrm{R}$ & $\mathrm{R}$ \\
& $\mathrm{S}$ & $\mathrm{S}$ & $\mathrm{S}$ & $\mathrm{S}$ & $\mathrm{S}$ & $\mathrm{S}$ & $\mathrm{S}$ & $\mathrm{S}$ \\
& 1 & 2 & 3 & 4 & 5 & 6 & 7 & 8 \\
\hline 1. Surface with non-slip & $\sqrt{ }$ & $\sqrt{ }$ & $\sqrt{ }$ & $\sqrt{ }$ & $\sqrt{ }$ & $\sqrt{ }$ & $\sqrt{ }$ & $\sqrt{ }$ \\
\hline $\begin{array}{l}\text { 2. Clear width (min 1200mm } \\
\text { - enable wheelchair) }\end{array}$ & $\sqrt{ }$ & $\sqrt{ }$ & $\sqrt{ }$ & $\sqrt{ }$ & $\sqrt{ }$ & $\sqrt{ }$ & $\sqrt{ }$ & $\sqrt{ }$ \\
\hline 3. Properly connected & $\sqrt{ }$ & $\sqrt{ }$ & $\sqrt{ }$ & $\sqrt{ }$ & $\sqrt{ }$ & $\sqrt{ }$ & $\sqrt{ }$ & $\sqrt{ }$ \\
\hline
\end{tabular}

Note: $\sqrt{\text { Comply }} \mathrm{x}$ Not comply

All stations had complied with the walkway standards. However, the size and material of walkway at RS1 differs from other stations in Perak.

\subsubsection{Analysis of the doorway at main entrance}

All stations complied with the only one standard outlined by the SIRIM.

Table 4. Analysis of doorway at main entrance towards MS

\begin{tabular}{|l|c|c|c|c|c|c|c|c|}
\hline \multirow{2}{*}{ Standards } & \multicolumn{7}{|c|}{ Compliance } \\
\cline { 2 - 8 } & $\mathrm{R}$ & $\mathrm{R}$ & $\mathrm{R}$ & $\mathrm{R}$ & $\mathrm{R}$ & $\mathrm{R}$ & $\mathrm{R}$ & $\mathrm{R}$ \\
& $\mathrm{S}$ & $\mathrm{S}$ & $\mathrm{S}$ & $\mathrm{S}$ & $\mathrm{S}$ & $\mathrm{S}$ & $\mathrm{S}$ & $\mathrm{S}$ \\
& 1 & 2 & 3 & 4 & 5 & 6 & 7 & 8 \\
\hline $\begin{array}{l}\text { 1. Doorway width is } \\
\text { adequate for wheelchair } \\
\text { user (min 900mm width) }\end{array}$ & $\sqrt{ }$ & $\sqrt{ }$ & $\sqrt{ }$ & $\sqrt{ }$ & $\sqrt{ }$ & $\sqrt{ }$ & $\sqrt{ }$ & $\sqrt{ }$ \\
\hline $\begin{array}{l}\text { 2. Threshold is leveled with } \\
\text { step ramp (if any) }\end{array}$ & $\mathrm{x}$ & $\mathrm{x}$ & $\mathrm{x}$ & $\mathrm{x}$ & $\mathrm{x}$ & $\mathrm{x}$ & $\mathrm{x}$ & $\mathrm{x}$ \\
\hline
\end{tabular}

Note: $\sqrt{ }$ Comply $\mathrm{x}$ Not comply

All main entrance doors have adequate width to enable the wheelchair user to pass through the doors. There is no threshold provided at any station because the surface of the main entrance doorway on the premises is flat.

\subsubsection{Analysis of ticket counter}

In general, all stations in Perak had complied with the standard of MS. Each station provides a special counter and it is accessible to the PWDs.

\subsubsection{Analysis of disabled parking}

There are six standards of disabled parking to be observed at all stations. This is shown in Table 5.

\footnotetext{
a harya966@perak.uitm.edu.my
} 
Table 5. Analysis of disabled parking towards MS

\begin{tabular}{|c|c|c|c|c|c|c|c|c|c|}
\hline \multirow[t]{2}{*}{ Standards } & \multicolumn{8}{|c|}{ Compliance } & \multirow[b]{2}{*}{ Remarks } \\
\hline & $\begin{array}{l}\mathrm{R} \\
\mathrm{S} \\
1\end{array}$ & $\begin{array}{l}\mathrm{R} \\
\mathrm{S} \\
2\end{array}$ & $\begin{array}{l}\mathrm{R} \\
\mathrm{S} \\
3\end{array}$ & $\begin{array}{l}\mathrm{R} \\
\mathrm{S} \\
4\end{array}$ & $\begin{array}{l}\mathrm{R} \\
\mathrm{S} \\
5\end{array}$ & $\begin{array}{l}\mathrm{R} \\
\mathrm{S} \\
6\end{array}$ & $\begin{array}{l}\mathrm{R} \\
\mathrm{S} \\
7\end{array}$ & $\begin{array}{l}\mathrm{R} \\
\mathrm{S} \\
8\end{array}$ & \\
\hline 1. Located at the main entrance & $\sqrt{ }$ & $\sqrt{ }$ & $\sqrt{ }$ & $\sqrt{ }$ & $\sqrt{ }$ & $\sqrt{ }$ & $\sqrt{ }$ & $\sqrt{ }$ & $\begin{array}{l}\text { - Only one disabled parking at RS1 } \\
\text { - Two disabled parking at RS2, } \\
\text { RS3, RS4. RS5. RS6, RS7 and } \\
\text { RS8 }\end{array}$ \\
\hline 2. Located at the flat surface & $\sqrt{ }$ & $\sqrt{ }$ & $\sqrt{ }$ & $\sqrt{ }$ & $\sqrt{ }$ & $\sqrt{ }$ & $\sqrt{ }$ & $\sqrt{ }$ & \\
\hline 3. With adequate width $(2400 \mathrm{~mm})$ & $\sqrt{ }$ & $\sqrt{ }$ & $\sqrt{ }$ & $\sqrt{ }$ & $\sqrt{ }$ & $\sqrt{ }$ & $\sqrt{ }$ & $\sqrt{ }$ & \\
\hline $\begin{array}{l}\text { 4. There is a signage indicating the } \\
\text { parking }\end{array}$ & $\sqrt{ }$ & $\sqrt{ }$ & $\sqrt{ }$ & $\sqrt{ }$ & $\mathrm{X}$ & $\mathrm{x}$ & $\mathrm{x}$ & $\mathrm{x}$ & \\
\hline $\begin{array}{l}\text { 5. Marking indicating disabled } \\
\text { parking }\end{array}$ & $\mathrm{x}$ & $\sqrt{ }$ & $\sqrt{ }$ & $\sqrt{ }$ & $\sqrt{ }$ & $\sqrt{ }$ & $\sqrt{ }$ & $\sqrt{ }$ & $\begin{array}{l}\text { Marking indicating disabled parking } \\
\text { at RS3 and RS4 are not up to the } \\
\text { SIRIM standard }\end{array}$ \\
\hline $\begin{array}{l}\text { 6. Enough space for wheelchair user } \\
\text { to maneuver (extra space min } \\
900 \mathrm{~mm} \text { ) }\end{array}$ & $\mathrm{X}$ & $\mathrm{X}$ & $\sqrt{ }$ & $\sqrt{ }$ & $\sqrt{ }$ & $\sqrt{ }$ & $\sqrt{ }$ & $\mathrm{x}$ & \\
\hline
\end{tabular}

Note: $\sqrt{ }$ Comply $\mathrm{x}$ Not comply

Although all stations have provided disabled parking, only RS3 and RS4 comply with all the standards. However, both stations did not comply with the disabled marking sign as outlined by the Standards and Industrial Research Institute of Malaysia (SIRIM). Instead of using the disabled symbol, it only uses the cross line marking.

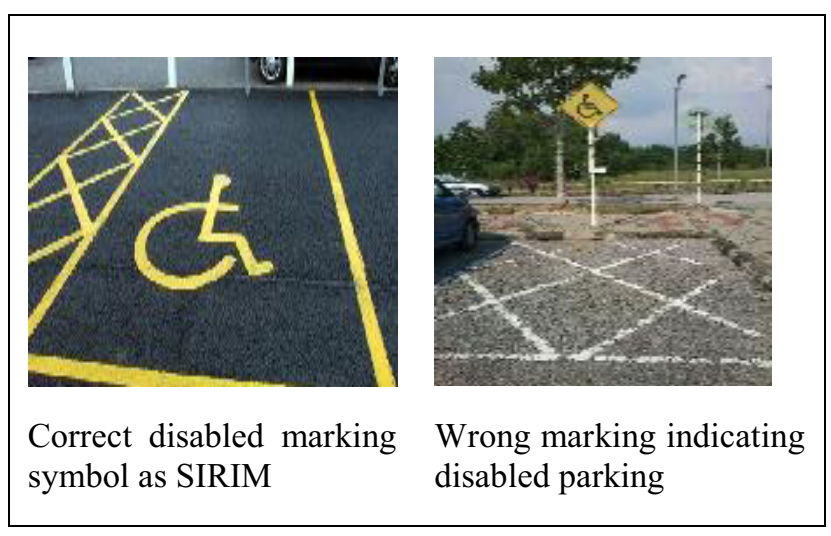

Figure 2. Disabled parking marking symbol

The disabled parking provided at all stations are located at the main entrance and on a flat surface with adequate width of $2400 \mathrm{~mm}$ except there are inadequate space provided. However, the space is inadequate for a wheelchair user to maneuver from the car. This is observed at RS1, RS2 and RS8.

It is also found that, signage indicating disabled parking is not complaint to the incomply standard at all stations. This is mostly due to vandalism There is also construction wastages found at the walkway to the disabled parking in RS6 and may expose the PWDs to the risk of accident.

\subsubsection{Analysis of signage}

Generally, all stations have provided signage . However, none had complied with all standards listed in the checklist. There is no signage provided at parking area at RS6, RS7 and RS8. In addition, there is no signage with braille instruction provided. This is important especially for disabled person with sight impairment.

Table 6. Analysis of signage towards MS

\begin{tabular}{|c|c|c|c|c|c|c|c|c|}
\hline \multirow{4}{*}{ Standards } & \multicolumn{8}{|c|}{ Compliance } \\
\hline & $\mathrm{R}$ & $\mathrm{R}$ & $\mathrm{R}$ & $\mathrm{R}$ & $\mathrm{R}$ & $\mathrm{R}$ & $\mathrm{R}$ & $\mathrm{R}$ \\
\hline & $\mathrm{S}$ & $\mathrm{S}$ & $\mathrm{S}$ & $\mathrm{S}$ & $\mathrm{S}$ & $\mathrm{S}$ & $\mathrm{S}$ & $\mathrm{S}$ \\
\hline & 1 & 2 & 3 & 4 & 5 & 6 & 7 & 8 \\
\hline $\begin{array}{l}\text { 1. Signage is installed at } \\
\text { proper locations }\end{array}$ & & & & & & & & \\
\hline a) Parking area & $\sqrt{ }$ & $\sqrt{ }$ & $\sqrt{ }$ & $\sqrt{ }$ & $\mathrm{x}$ & $\mathrm{x}$ & $\mathrm{x}$ & $\sqrt{ }$ \\
\hline b) Walkway & $\sqrt{ }$ & $\sqrt{ }$ & $\sqrt{ }$ & $\sqrt{ }$ & $\sqrt{ }$ & $\sqrt{ }$ & $\sqrt{ }$ & $\sqrt{ }$ \\
\hline $\begin{array}{l}\text { c) Main } \\
\text { entrance/doorway }\end{array}$ & $\sqrt{ }$ & $\sqrt{ }$ & $\sqrt{ }$ & $\sqrt{ }$ & $\sqrt{ }$ & $\sqrt{ }$ & $\sqrt{ }$ & $\sqrt{ }$ \\
\hline d) Toilet & $\sqrt{ }$ & $\sqrt{ }$ & $\sqrt{ }$ & $\sqrt{ }$ & $\sqrt{ }$ & $\sqrt{ }$ & $\sqrt{ }$ & $\sqrt{ }$ \\
\hline e) Platform & $\sqrt{ }$ & $\sqrt{ }$ & $\sqrt{ }$ & $\sqrt{ }$ & $\sqrt{ }$ & $\sqrt{ }$ & $\sqrt{ }$ & $\sqrt{ }$ \\
\hline f) Ticket counter & $\sqrt{ }$ & $\sqrt{ }$ & $\sqrt{ }$ & $\sqrt{ }$ & $\sqrt{ }$ & $\sqrt{ }$ & $\sqrt{ }$ & $\sqrt{ }$ \\
\hline $\begin{array}{l}\text { 2. Clearly provide the } \\
\text { direction/information }\end{array}$ & $\sqrt{ }$ & $\sqrt{ }$ & $\sqrt{ }$ & $\sqrt{ }$ & $\sqrt{ }$ & $\sqrt{ }$ & $\sqrt{ }$ & $\sqrt{ }$ \\
\hline $\begin{array}{l}\text { 3. Signage } \\
\text { illuminated/lighted }\end{array}$ & $\sqrt{ }$ & $\sqrt{ }$ & $\sqrt{ }$ & $\sqrt{ }$ & $\sqrt{ }$ & $\sqrt{ }$ & $\mathrm{x}$ & $\sqrt{ }$ \\
\hline $\begin{array}{l}\text { 4. Signage equipped with } \\
\text { Braille instruction }\end{array}$ & $\mathrm{X}$ & $\mathrm{x}$ & $\mathrm{x}$ & $\mathrm{x}$ & $\mathrm{X}$ & $\mathrm{X}$ & $\mathrm{x}$ & $\mathrm{x}$ \\
\hline
\end{tabular}

Note: $\sqrt{ }$ Comply $x$ Not comply

RS7 is observed to be the most incompliant station in providing this facility. Besides no not having any signage in braille signage instruction, there is also no signage provided at the parking area and the signage is not illuminated. . Similarly, problems are also found at RS5 and RS6.

\footnotetext{
a harya966@perak.uitm.edu.my
} 
Table 7. Analysis of ramp and kerb towards MS

\begin{tabular}{|c|c|c|c|c|c|c|c|c|c|}
\hline \multirow[b]{2}{*}{ Standards } & \multicolumn{8}{|c|}{ Compliance } & \multirow[b]{2}{*}{ Remarks } \\
\hline & $\begin{array}{l}\mathrm{R} \\
\mathrm{S} \\
1\end{array}$ & $\begin{array}{l}\mathrm{R} \\
\mathrm{S} \\
2\end{array}$ & $\begin{array}{l}\mathrm{R} \\
\mathrm{S} \\
3\end{array}$ & $\begin{array}{l}\mathrm{R} \\
\mathrm{S} \\
4\end{array}$ & $\begin{array}{l}\mathrm{R} \\
\mathrm{S} \\
5\end{array}$ & $\begin{array}{l}\mathrm{R} \\
\mathrm{S} \\
6\end{array}$ & $\begin{array}{l}\mathrm{R} \\
\mathrm{S} \\
7\end{array}$ & $\begin{array}{l}\mathrm{R} \\
\mathrm{S} \\
8\end{array}$ & \\
\hline $\begin{array}{l}\text { 1. Ramp consists of landing (min } \\
\text { length } 1200 \mathrm{~mm} \text { ) at interval of not } \\
\text { more than } 600 \mathrm{~mm} \text { length of ramp) }\end{array}$ & $\sqrt{ }$ & $\sqrt{ }$ & $\sqrt{ }$ & $\sqrt{ }$ & $\sqrt{ }$ & $\sqrt{ }$ & $\sqrt{ }$ & $\sqrt{ }$ & Two ramps provided at all stations \\
\hline 2. Surface with non-slip & $\sqrt{ }$ & $\sqrt{ }$ & $\sqrt{ }$ & $\sqrt{ }$ & $\sqrt{ }$ & $\sqrt{ }$ & $\sqrt{ }$ & $\sqrt{ }$ & \\
\hline $\begin{array}{l}\text { 3. Enable wheelchair user(1200mm } \\
\text { min width) }\end{array}$ & $\sqrt{ }$ & $\sqrt{ }$ & $\sqrt{ }$ & $\sqrt{ }$ & $\sqrt{ }$ & $\sqrt{ }$ & $\sqrt{ }$ & $\sqrt{ }$ & \\
\hline $\begin{array}{l}\text { 4. Proper gradient (Max 1:12-min } \\
1: 20)\end{array}$ & $\sqrt{ }$ & $\sqrt{ }$ & $\sqrt{ }$ & $\sqrt{ }$ & $\sqrt{ }$ & $\sqrt{ }$ & $\sqrt{ }$ & $\sqrt{ }$ & \\
\hline $\begin{array}{l}\text { 5. Provided with handrails at both } \\
\text { sides }\end{array}$ & $\sqrt{ }$ & $\mathrm{x}$ & $\mathrm{X}$ & $\mathrm{X}$ & $\mathrm{X}$ & $\mathrm{X}$ & $\mathrm{X}$ & $\mathrm{X}$ & $\begin{array}{l}\text { Only one side } \\
\text { No handl at RS6 } \\
\text { Inadequate length of ramp }\end{array}$ \\
\hline $\begin{array}{l}\text { 6. Kerb is provided at both sides } \\
\text { (min } 100 \mathrm{~mm} \text { length) }\end{array}$ & $\sqrt{ }$ & $\mathrm{x}$ & $\mathrm{x}$ & $\mathrm{X}$ & $\mathrm{X}$ & $\mathrm{x}$ & $\mathrm{X}$ & $\mathrm{X}$ & No kerb provided except at RS1 \\
\hline
\end{tabular}

Note: $\sqrt{ }$ Comply $x$ Not comply

\subsubsection{Analysis of ramp and kerb}

Table 7 listed all six standards of ramp and kerb to be complied at all stations. Although all stations provide ramp, only RS1 complies with all standards in the checklist. Meanwhile, for the other stations, there is only one handrail or wall provided at both sides of ramp. It is also found that, one of the ramps at RS6 has no handrail and does not comply with the standard length. Thus, the wheelchair user might encounter difficulty to pass through this facility.

It is also observed that there is no kerb provided to prevent the wheelchair user from falling at RS2, RS3, RS4, RS5, RS6, RS7 and RS8 because there is a handrail or wall built at both sides.

\subsubsection{Analysis of handrail}

There are four standards to be complied when providing this facility. This is outlined in the table below.

Table 8. Analysis of handrail towards MS

\begin{tabular}{|l|c|c|c|c|c|c|c|c|}
\hline & \multicolumn{7}{|c|}{ Compliance } \\
\cline { 2 - 8 } Standards & $\mathrm{R}$ & $\mathrm{R}$ & $\mathrm{R}$ & $\mathrm{R}$ & $\mathrm{R}$ & $\mathrm{R}$ & $\mathrm{R}$ & $\mathrm{R}$ \\
& $\mathrm{S}$ & $\mathrm{S}$ & $\mathrm{S}$ & $\mathrm{S}$ & $\mathrm{S}$ & $\mathrm{S}$ & $\mathrm{S}$ & $\mathrm{S}$ \\
& 1 & 2 & 3 & 4 & 5 & 6 & 7 & 8 \\
\hline $\begin{array}{l}\text { 1. Fixed with proper } \\
\text { height at ramp (min } \\
840-900 \mathrm{~mm} \text { in height) }\end{array}$ & $\sqrt{ }$ & $\sqrt{ }$ & $\sqrt{ }$ & $\sqrt{ }$ & $\sqrt{ }$ & $\sqrt{ }$ & $\sqrt{ }$ & $\sqrt{ }$ \\
\hline $\begin{array}{l}\text { 2. At ramp/stairway - } \\
\text { extended 300mm in } \\
\text { length at both sides }\end{array}$ & $\sqrt{ }$ & $\sqrt{ }$ & $\sqrt{ }$ & $\sqrt{ }$ & $\sqrt{ }$ & $\sqrt{ }$ & $\sqrt{ }$ & $\sqrt{ }$ \\
\hline 3. Contrast in colour & $\sqrt{ }$ & $\sqrt{ }$ & $\sqrt{ }$ & $\sqrt{ }$ & $\sqrt{ }$ & $\sqrt{ }$ & $\sqrt{ }$ & $\sqrt{ }$ \\
\hline $\begin{array}{l}\text { 4. Surface with non-slip } \\
\text { grip }\end{array}$ & N/A & $\mathrm{x}$ & $\mathrm{x}$ & $\mathrm{x}$ & $\mathrm{x}$ & $\mathrm{x}$ & $\mathrm{x}$ & $\mathrm{x}$ \\
\hline
\end{tabular}

All stations had provided handrail for PWD except for RS1., However, the handrail is not covered with a nonslip material to prevent from sweat, slippery and fall.

\subsubsection{Analysis of prayer room}

There are four standards of PWD prayer room as highlighted by the MS. All stations provide prayer room except RS1. It is found that all prayer rooms complies to all the standards required except for the provision of ramp in the prayer room and at the ablution area.

Table 9. Analysis of prayer room towards MS

\begin{tabular}{|c|c|c|c|c|c|c|c|c|}
\hline \multirow{4}{*}{ Standards } & \multicolumn{8}{|c|}{ Compliance } \\
\hline & $\mathrm{R}$ & $\mathrm{R}$ & $\mathrm{R}$ & $\mathrm{R}$ & $\mathrm{R}$ & $\mathrm{R}$ & $\mathrm{R}$ & $\mathrm{R}$ \\
\hline & $\mathrm{S}$ & $\mathrm{S}$ & $\mathrm{S}$ & $\mathrm{S}$ & $\mathrm{S}$ & $\mathrm{S}$ & $\mathrm{S}$ & $\mathrm{S}$ \\
\hline & 1 & 2 & 3 & 4 & 5 & 6 & 7 & \\
\hline $\begin{array}{l}\text { 1. Ablution area accessible } \\
\text { to wheelchair user }\end{array}$ & \multirow{4}{*}{$\begin{array}{l}\mathrm{N} \\
/ \\
\mathrm{A}\end{array}$} & $\sqrt{ }$ & $\sqrt{ }$ & $\sqrt{ }$ & $\sqrt{ }$ & $\sqrt{ }$ & $\sqrt{ }$ & $\sqrt{ }$ \\
\hline $\begin{array}{l}\text { 2. Door width accessible to } \\
\text { wheelchair user }\end{array}$ & & $\sqrt{ }$ & $\sqrt{ }$ & $\sqrt{ }$ & $\sqrt{ }$ & $\sqrt{ }$ & $\sqrt{ }$ & $\sqrt{ }$ \\
\hline 3. Step ramp at door & & $\mathrm{x}$ & $\mathrm{x}$ & $\mathrm{x}$ & $\mathrm{x}$ & $\mathrm{x}$ & $\mathrm{x}$ & $\mathrm{x}$ \\
\hline $\begin{array}{ll}\text { 4. Floor with non-slip } \\
\text { surface }\end{array}$ & & $\sqrt{ }$ & $\sqrt{ }$ & $\sqrt{ }$ & $\sqrt{ }$ & $\sqrt{ }$ & $\sqrt{ }$ & $v$ \\
\hline
\end{tabular}

Note: $\sqrt{ }$ Comply $x$ Not comply

\subsubsection{Analysis of the special lane for wheelchair users to Platform 2}

The purpose of this special lane is to ease the wheelchair users to travel from Platform 1 to Platform 2. It is observed that all stations had provided this facility. However, its location is far from the main area at the platform. 
Table 10. Analysis of guiding block towards MS

\begin{tabular}{|c|c|c|c|c|c|c|c|c|c|}
\hline \multirow{4}{*}{ Standards } & \multicolumn{8}{|c|}{ Compliance } & \multirow{4}{*}{ Remarks } \\
\hline & $\mathrm{R}$ & $\mathrm{R}$ & $\mathrm{R}$ & $\mathrm{R}$ & $\mathrm{R}$ & $\mathrm{R}$ & $\mathrm{R}$ & $\mathrm{R}$ & \\
\hline & $\mathrm{S}$ & S & $\mathrm{S}$ & $\mathrm{S}$ & S & $\mathrm{S}$ & $\mathrm{S}$ & $\mathrm{S}$ & \\
\hline & 1 & 2 & 3 & 4 & 5 & 6 & 7 & 8 & \\
\hline 1. Installed at proper location & $\sqrt{ }$ & $\sqrt{ }$ & $\sqrt{ }$ & $\sqrt{ }$ & $\sqrt{ }$ & $\sqrt{ }$ & $\sqrt{ }$ & $\sqrt{ }$ & $\begin{array}{l}\text { Not installed at all important areas } \\
\text { except for RS3 }\end{array}$ \\
\hline $\begin{array}{l}\text { 2. Each block is installed adjacent to } \\
\text { one another }\end{array}$ & $\sqrt{ }$ & $\sqrt{ }$ & $\sqrt{ }$ & $\sqrt{ }$ & $\sqrt{ }$ & $\sqrt{ }$ & $\sqrt{ }$ & $\sqrt{ }$ & \\
\hline 3. Contrast in colour & $\sqrt{ }$ & $\sqrt{ }$ & $\sqrt{ }$ & $\sqrt{ }$ & $\sqrt{ }$ & $\sqrt{ }$ & $\sqrt{ }$ & $\sqrt{ }$ & \\
\hline 4. Detectable underfoot & $\sqrt{ }$ & $\sqrt{ }$ & $\sqrt{ }$ & $\sqrt{ }$ & $\sqrt{ }$ & $\sqrt{ }$ & $\sqrt{ }$ & $\sqrt{ }$ & $\begin{array}{l}\text { Some of the blocks provided is } \\
\text { undetectable except at RS3 }\end{array}$ \\
\hline
\end{tabular}

Note: $\sqrt{ }$ Comply $\mathrm{x}$ Not comply

\subsubsection{Analysis of guiding block}

Guiding block is detectable underfoot and paced at all main areas at the station such as disabled toilet, ticket counter and ramp. The purpose of this facility is to help the PWD, particularly with sight impairment to aware of danger in front using their touch sensing of the feet. Thus, they can independently and safely access the station.

Table 10 shows that all stations comply with standards outlined in the MS. Nevertheless, only RS3 complied with all the standards.

\subsubsection{Analysis of disabled tolet}

There are six standards to be complied in the provision of disabled toilet in public railway stations.. All stations had provided disabled toilet and complied with the MS standards. However, it is found that all doors at the disabled toilet do not follows the standards and causes difficulty to the wheelchair users.

All disabled toilets at RS3, RS5, RS7 and RS8, are closed cannot be used are closed to avoid vandalism. Meanwhile, the disabled toilets at RS3, RS5 and RS8 are also closed due to poor maintenance of this facility.

\subsubsection{Analysis of elevator and escalator}

There are five standards for elevator and one standard for escalator. Only two stations i.e RS1 and RS3 provide elevator in its premises. . or However, for stations that has no elevator, the PWDs can use the special lane provided. All elevators provided complied with the standards as outlined in the checklist.

Escalator is only provided at RS1 because it is the largest ETS station in Perak. Nonetheless, there is no guiding block provided in front of the escalator, as required by the standard.

\section{Discussions}

The findings indicate that although all ETS stations in Perak are attempting to accommodate the PWDs needs, there are several facilities that are in comply with the MS. This is in-line with [10] stating that most of the public buildings in Malaysia are still lacking in the provision of user-friendly built environment for the disabled persons. Inaccessibility found in some stations is mainly due to poor design, poor planning, poor maintenance and lack of enforcement on guidelines provided.

It is also reveals that braille signage is something that could be uncommonly seen in the stations. According to [11,12]Corn (1990), Small et al (2012) and Syazwani \& Mariam, 2012), difficulties in way finding by either the visual or hearing impairment persons will significantly contributes to safety and comfort issues, particularly when they are travelling alone. Meanwhile, the provision of adequate gradient of ramp, size of disabled parking, height of ticket counters and special lane for travelling are important facilities to be provided for the wheelchair users. Adding into this, [12] also recommended that the public facilities should be designed not merely for the PWDs but also to greatest scope as possible, including common people such as children, parents with baby stroller, expectant mothers, library staff caring huge stack of books and elder people.

Clearly, this research has provided some benchmark for planners, local authority and designers in planning and designing or even in improving the existing disabled facilities provided in the ETS stations. This is crucially important so that the PWDs will no longer feel isolated for the continuous development that is becoming more challenging.

\section{Conclusions}

This research would significantly promote and enhance the public buildings for better value by focusing on the disabled friendly facilities. Moreover, it also promotes the friendliness atmosphere of the ETS railway stations for better usage and accessibility.

Finally, in improving or designing the public transport stations, feedback from the users are utmost important. There are also needs for more innovative and good design to create a barrier-free environment and infrastructure.

\section{References}

1. Jayasooria, D, Krishnan, B, and Ooi, G. (1997). Disabled people in a newly industrializing economy: Opportunities and challenges in Malaysia. Disability and Society, 12(3), 455-463

\footnotetext{
a harya966@perak.uitm.edu.my
} 
2. Kennedy, M.K, and B. Hesla. (2008). We have human rights, Harvard Project on Disability, Harvard

3. Kamaruddin, H. (2007). The implementation of the SIRIM Codes of Practice for Disabled Persons by $D B K L$. University Technology MARA Malaysia. Unpublished dissertation

4. Hikmah, K., Ahmad, E.H., Mahayuddin, M, Nor Rima, M. A., and Wan Zurea, W.I. (2012). The implementation of the Malaysian Standard Code of Practice on Access for Disabled Persons by Local Authority. Procedia-Social and Behavioral Sciences, 50(2), 442-451

5. Soltani, S.H.K., Abbas, M.Y., Awang, M.B. and Yaman, R. (2012). Accessibility for disabled in public transportation terminal. Procedia-Social and Behavioral Sciences, 35(2), 78-86

6. Hafizuddin, M. (2013). Provision of facilities for disabled people in electric train service (ETS) railway station in Perak Darul Ridzuan. University Technology MARA Malaysia. Unpublished dissertation

7. Ahmad, E.H., Faridah, I., Zarina, I., Natasha, K. and Mardhati, A.R. (2011). Disabled facilities in shopping malls: Malaysians perspective. Business and Management Quarterly Review, 2(4), 56-64

8. Fairuzzana, A.P., and Fuziah, I. (2012). Accessibility of visually impaired passengers at urban railway stations in the Klang Valley. International Transactional Journal of Engineering, Management \& Applied Sciences \& Technologies, 3(3), 277-292

9. Seyed Hassan, K.S., Mashita, S., Mohamad, A. and Rostam, Y. (2011). Accessibility for disabled in public transportation terminal. Procedia-Social and Behavioral Sciences, 35(1), 89-96

10. Kamaruddin, H., Muhamad Ariff, N.R., Wan Zurea, W.I., Bakri, A.F., and Zarina, I. (2014). Malaysian scenario on access and facilities for persons with disabilities: A literature review. MATEC Web of Conferences

11. Jennie, S., Simon, D. and Tanya, P. (2012). The embodied tourist experiences of people with vision impairment: Management implications beyond the visual gaze. Tourist Management, 33(1), 941-950

12. Syazwani, A.K. and Mariam, J. (2012). Users' satisfaction and perception on accessibility of public buildings in Putrajaya: Access audit study. Procedia-Social and Behavioral Sciences, 50(2), 429-441 